\title{
History of the terrestrial environment in the Quaternary of Denmark
}

\author{
SVEND TH. ANDERSEN
}

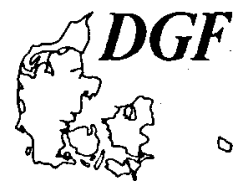

\begin{abstract}
Andersen, S. T.: History of the terrestrial environment in the Quaternary of Denmark. Bulletin of the Geological Society of Denmark, Vol. 41, pp. 219-228. Copenhagen 1994-11-30.

https://doi.org/10.37570/bgsd-1995-41-18

Changes in the environment backward in time can be reconstructed by measurement of geophysical, geochemical or palaeolontological paramenters in sediment columns. Changes in the elemental spheres of the environment are forced by changes in insolation and by mutual interactions. The glacial-interglacial cycles are provoked by minima and maxima in insolation and reflect changes in biosphere and geosphere. The last summer insolation maximum in the Northern Hemisphere coincides with the beginning of the Holocene. Decreasing insolation affected the altitudes of the glacial equilibrium line and the tree line in Norway, and air humidity in Denmark. The reestablishment of deciduous woodland coincided with the temperature maximum. The introduction of agriculture caused increasing deforestation, especially in densely populated areas, where the agricultural exploitation expanded with increasing precipitation. The environment was increasingly affected by man up towards present time. The natural climate development may be changed by air pollution. Air pollution due to industrialisation is registered by increased deposition of airborne particles on bogs and in lakes, and pollution of aquatic environments by increased adduction of nutritional elements to freshwater lakes.
\end{abstract}

Svend Th. Andersen, Division of Geobotany, Geological Survey of Denmark, Thoravej 8, DK-2400 Copenhagen NV, Denmark. 20th November 1993.

\section{Introduction}

Changes in the environment can be reconstructed backward in time by measurement of geophysical, geochemical or palaeontological parameters in sediment columns. Time scales in the Quaternary cover millions, hundredthousands, thousands or hundreds of years. The detail of environmental reconstructions increases with the proximity to the present, not least in the latest thousands or hundreds of years. Here, anthropogenic changes in the environment surpass natural changes with increasing force.

The elementary spheres of the environment, the atmosphere, the geosphere, and the hydrosphere, can be pictured in a pyramid (Hansen 1984, Fig. 1.). In the common centre we find the biosphere. Influences are transmitted from the atmosphere to the geosphere and the hydrosphere, directly or via the biosphere. The common source of energy in this system is insolation. Hence, changes in insolation are a primary driving force in large-scale environmental change.

Insolation heats the surface of the geosphere, the continents, and the uneven heating of the Earth's surface triggers the climatic impacts. Changes in insolation are, therefore, decisive for the state of the environment. Longterm changes in insolation due to variations in the Earth's orbit, calculated in 1941 by M. Milankovitch, have now been recognized as a primary driving force in environmental changes of the Earth (Hays, Imbrie \& Shackleton 1976, Genthon, Barnola, Raynaud, Lorius, Jouzel, Barkov, Korotkevich \& Kotlyakov 1987, Emiliani 1993). Due to interaction between changes in eccentricity, inclination and precession, periodicities in insolation of $100.000,42.000$ and 23.000 years occur (Hays et al. 1976, Fig. 2, A).

A measure of the effect of changes in insolation on the temperature of the atmosphere was obtained by measurements of hydrogen isotopes in ice cores in Antarctis, where the reconstructed temperature curve follows the periodicity in insolation on the northern hemisphere (Jouzel, Lorius, Petit, Genthon, Barkov, Kotlyakov \& Petrov 1987, Fig. 2, B). Insolation in the northerm hemisphere, therefore, was decisive for the global temperature. The amplitudes of the temperature changes differ somewhat from the amplitudes of the insolation curve. This is explained mainly by a strong influence from variations in the $\mathrm{CO}_{2}$ content of the air (Genthon et al. 1987).

The changes in temperature caused by changes in insolation and the related changes in climate were decisive for changes in ocean surface temperature (Martinsson, Pisias, Hays, Imbrie, Moore \& Shackleton 1987, Fig. 2, C), the distribution of sea ice, and the ocean current system. Accordingly also the hydrosphere was affected by changes in insolation. Due to formation of ice on the 


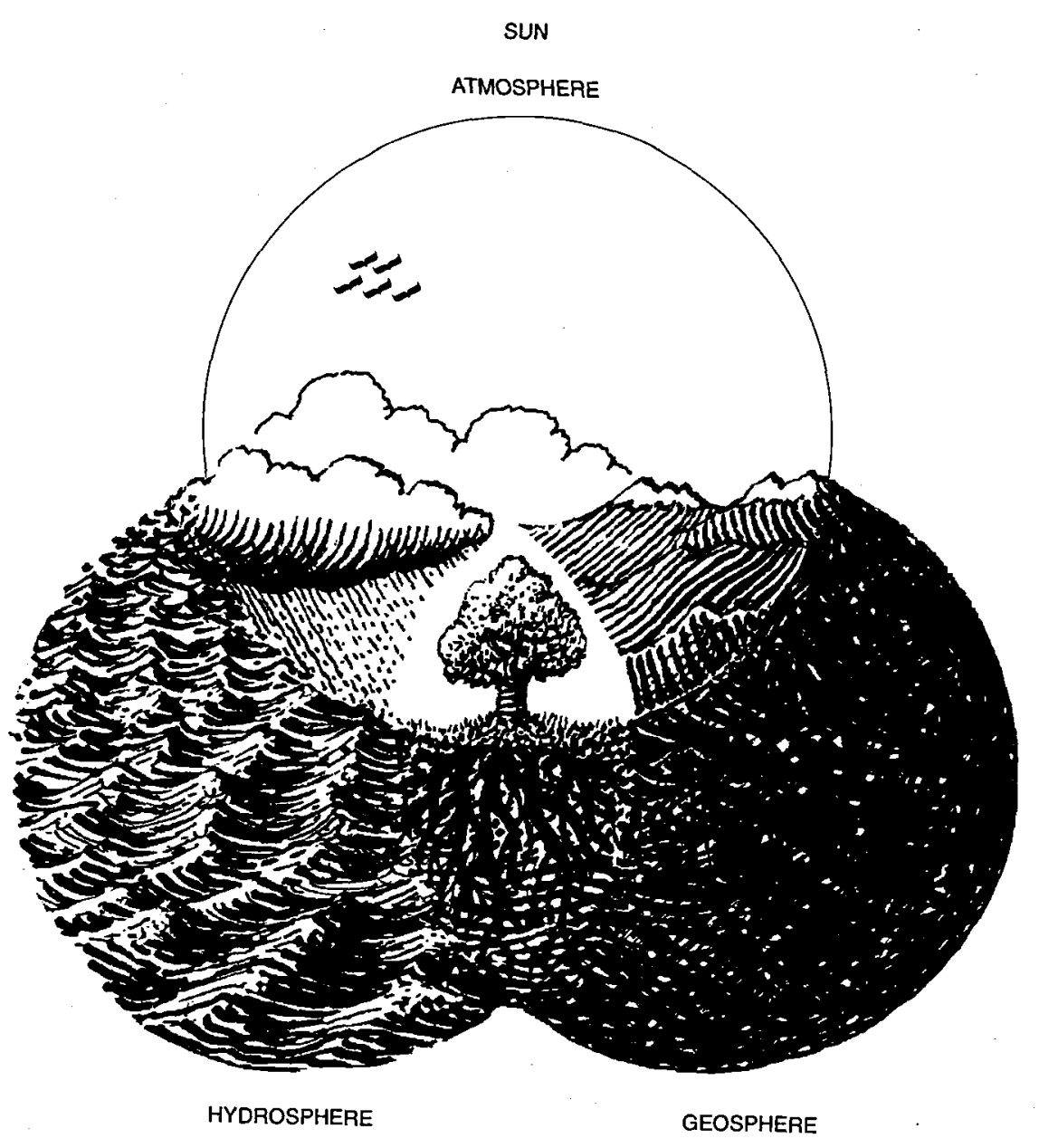

Fig. 1. The spheres of the environment: Atmosphere, hydrosphere, geosphere, and in the center: the biosphere (after Hansen 1984).

continents, the oceans were deprived of fresh water. Measurements of the ${ }^{18} 0$ content in sediment columns from the oceans reflect the depletion in fresh water, because the concentration of ${ }^{18} 0$ in the freshwater stored in the ice masses was lower than that of the sea water (Martinsson et al. 1987, Fig. 2, D). The variations in this curve follow the insolation curve, but the amplitudes are better correlated with the temperature amplitudes than with the insolation amplitudes (Genthon et al. 1987).

The long-term changes in insolation were also decisive for the biosphere. Temperature changes reconstructed from pollen analyses of terrestrial sediment columns therefore depend on changes in insolation (Guiot, Pons, Beaulieu \& Reille 1989, Fig. 2, E). The variations follow those of the insolation curve, but the amplitudes are smaller, indicating that the inferred changes in temperature were only secondarily influenced by the intensity of the insolation.
The glacial-interglacial cycle of the biosphere

The insolation curve and the temperature curves for the last 150.000 years indicate the highest values at about 120.000 years ago and again at about 10.000 years ago. These maxima coincide with interglacials, which occur backward in time with intervals of about 100.000 years, and were separated by cooler periods, the glacials (Emiliani 1993, Jouzel et al. 1993).

The glacial-interglacial cycle is reflected by changes between glaciations and ice-free periods in the north temperate latitudes (Fig. 2, D), and by changes in the latitudinal and altitudinal forest limit outside the glaciers (van der Hammen 1979). Southern France was forested during the Eemian Interglacial and in the first two Weichselian interstadials (Brørup and Odderade), and was without forest during the coolest part of the Weichselian Glacial (Fig. 3).

Iversen (1957) divided the glacial-interglacial cycle in ice-free areas with temperate climate in four stages according to changes in environment (Fig. 4, A): a cryocratic stage, with cold climate, cryoturbation and open 


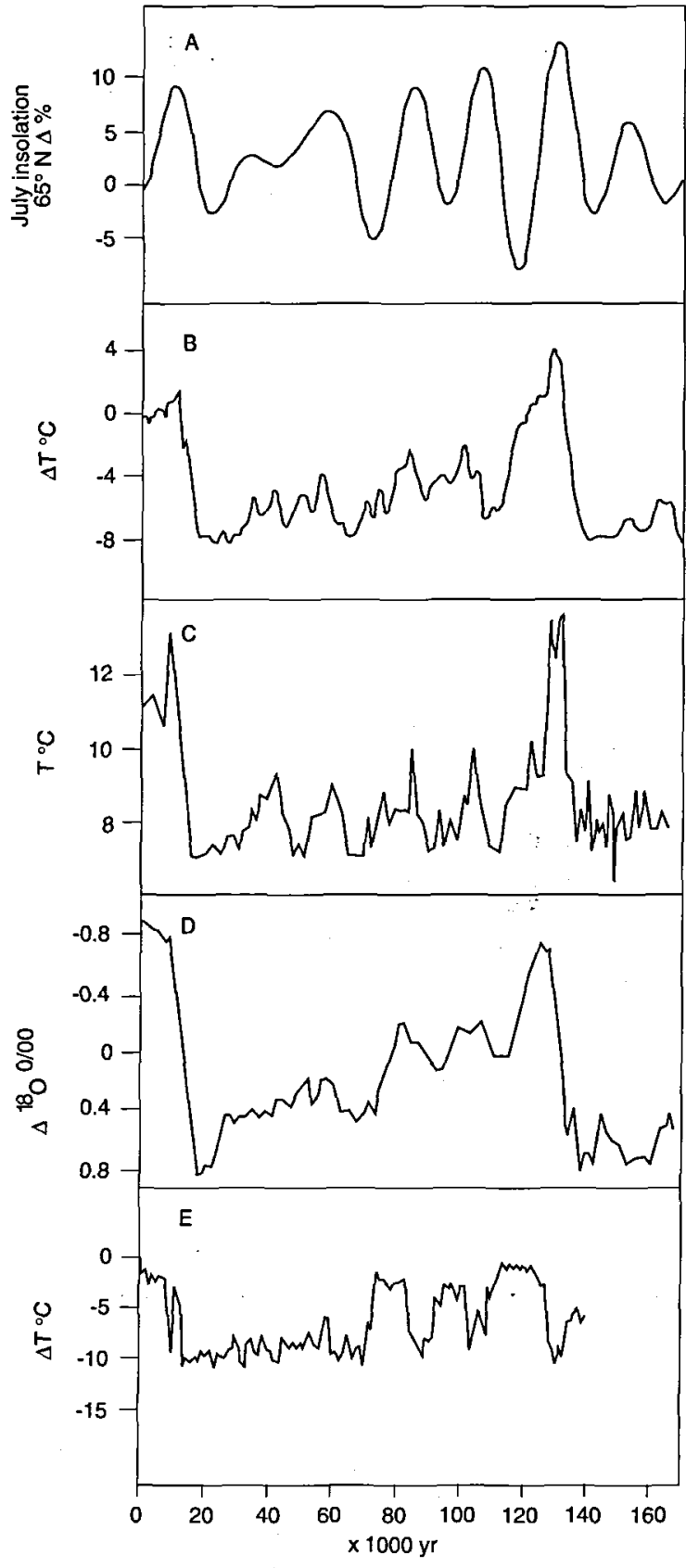

Fig. 2. Insolation and its influence on the environment during the last 150.000 years. A. Insolation in July at $65^{\circ} \mathrm{N}$, in percent deviation from the present value. B. Air temperature deviations from the present in ${ }^{\circ} \mathrm{C}$ based on the content of deuterium in the Vostok ice core from Antarctis. C. Surface temperature in the Indian Ocean. D. Normalized oxygen isotope $\left({ }^{18} 0\right)$ curve from deep sea sediments in the North Atlantic. E. Temperature deviation from the present in ${ }^{\circ} \mathrm{C}$ based on changes in vegetation in southern France. Compiled after Genthon et al. (1987), Jouzel et al. (1987), Martinson et al. (1987), Pons et al. (1991). vegetation, a protocratic stage, with increasing temperature, and invasion by light-demanding pioneer vegetation, a mesocratic stage with high temperature, establishment of dense deciduous woodland and development of brown earth soils, and a telocratic stage with decreasing temperature, leaching of soils and increasing open vegetation types. Andersen $(1966,1969)$ studying three interglacial cycles in Denmark, pointed out, that the leaching of soils was an autigenic process not provoked by external influences such as decreasing temperature and increasing humidity, as postulated by Iversen. The orginal model was therefore improved by the introduction of an oligocratic stage between Iversen's mesocratic and telocratic stages (Fig. 4, B, cf. Birks 1986). Impoverishment of the soils induced a decrease of the dense woodlands, formation of acid humus layers and the expansion of open vegetation in this stage. This development then culminated in the telocratic stage with widespread paludification.

Andersen $(1966,1969)$ emphasized common features in the three interglacial cycles studied by him despite fundamental differences in tree composition and immigrational sequence: the Harreskovian, the Holsteinian and the Eemian (Andersen 1965). There were three main vegetational elements: Vegetation of light-demanding plants without particular preferences to soil quality (grasses and other herbs, Betula, Pinus, Populus), woodland on brown earth requiring fertile soil (Ulmus, Corylus, Tilia, Carpinus, Fraxinus, Quercus), and vegetation on acid humus (Picea, Pteridium, Ericales, Myrica, Sphagnum). The participation of these elements in the interglacial sequences show common features (Fig. 5, A). The curves move from the lower right to the lower left corner, illustrating the change from the protocratic to the mesocratic stage, and then revert to the right and upwards, illustrating the change to increasingly open vegetation and acid soils in the oligocratic and the telocratic stages. The curve for the Holsteinian Interglacial differs from the two other curves because brown-earth woodland never reached dominance, and the mesocratic phase, therefore, was poorly developed. An explanation of this feature might be widespread occurrence of easily leachable, sandy soils (Andersen 1969).

The three interglacial successions studied in Denmark all indicate a progressive development without interruptions by catastrophic events. The uniformity of the climate throughout the mesocratic and oligocratic stages were pointed out by Andersen (1969), based on the occurrence of temperature-sensitive plants such as Hedera, Ilex, Buxus, Viscum, and others. This opinion contrasts the results from the GRIP ice-core in Greenland (Greenland ice-core project (GRIP) members 1993). This icecore indicates several severe coolings of seventy to several thousand year's duration during a generally warm period, which is correlated with the marine isotopic stage 5 e assumed to represent the Eemian Interglacial (Mangerud 1990). The cool events during stage $5 \mathrm{e}$ in the Greenland core have no counterparts in the pollen data from the 


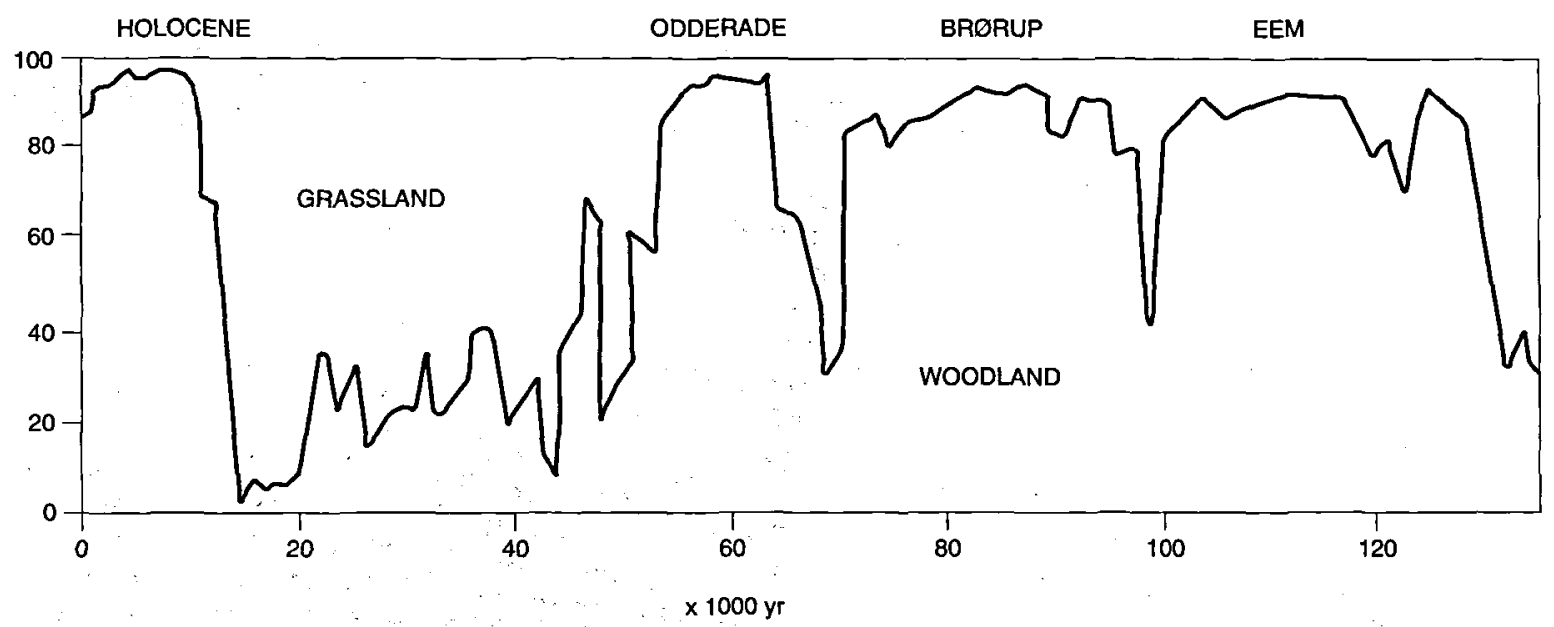

Fig. 3. Changes in percentages of tree pollen in lake sediments from southern France (after Pons, Beaulieu, Guiot \& Reille 1991).

Eemian in Denmark, and is not reflected in other palaeotemperature curves (Fig. 2). It is therefore an open question why these events have left no traces in other parts of the world.

The changes in the environment during the glacialinterglacial cycles outlined above were induced by natural forces such as temperature change and the influence of the biosphere on the geosphere. A new force, the influence of Man, became prominent in our present intergla- cial, the Holocene (Fig. 5, B). In the early Holocene, the change from vegetation of light-plants to dense brownearth woodland mirrored that of the Eemian Interglacial. From the mid-Holocene, about 6.000 years ago, the curve reverts to the right as in the Eemian. This change to dominant light-demanding vegetation was in the Holocene due to the artificial clearance of woodland. The development of acid-humus vegetation was weak on fertile soils, because leaching was retarded by the agricultu-
INTERGLACIAL

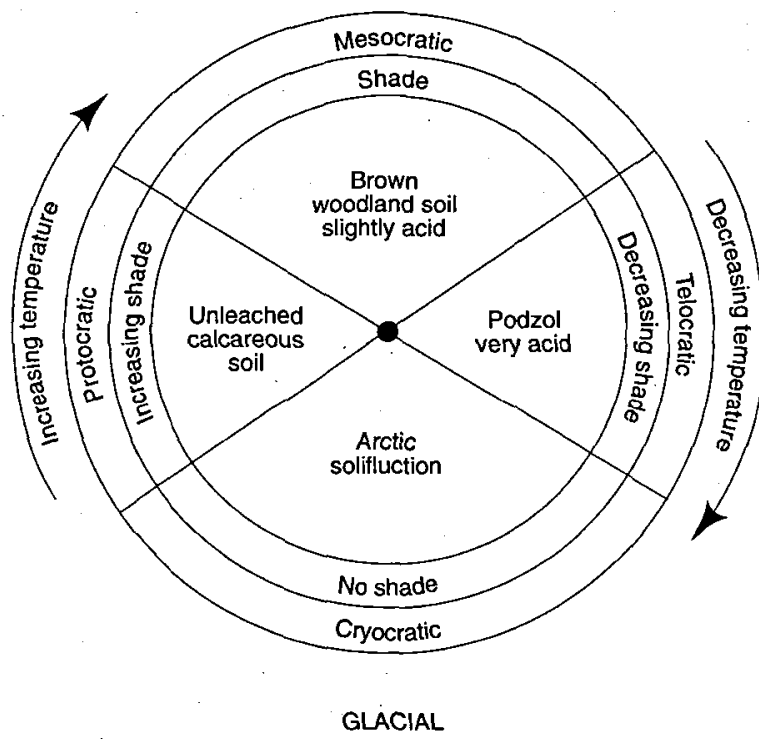

$A$
INTERGLACIAL

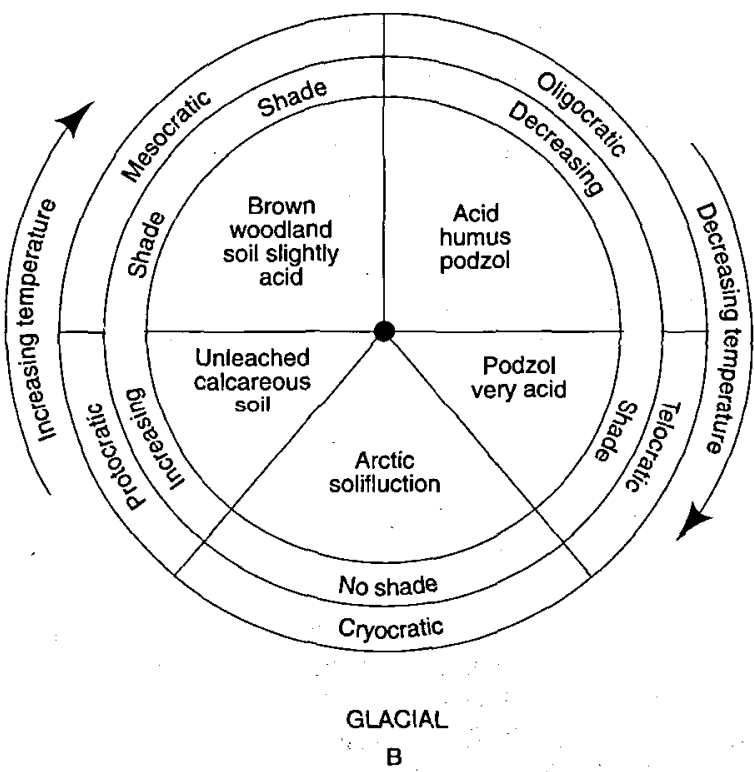

Fig. 4. The glacial-interglacial cycle of environmental change. A. After Iversen (1957). B. Present interpretation. The largest changes in temperature occurred in the protocratic and the telocratic stages. 

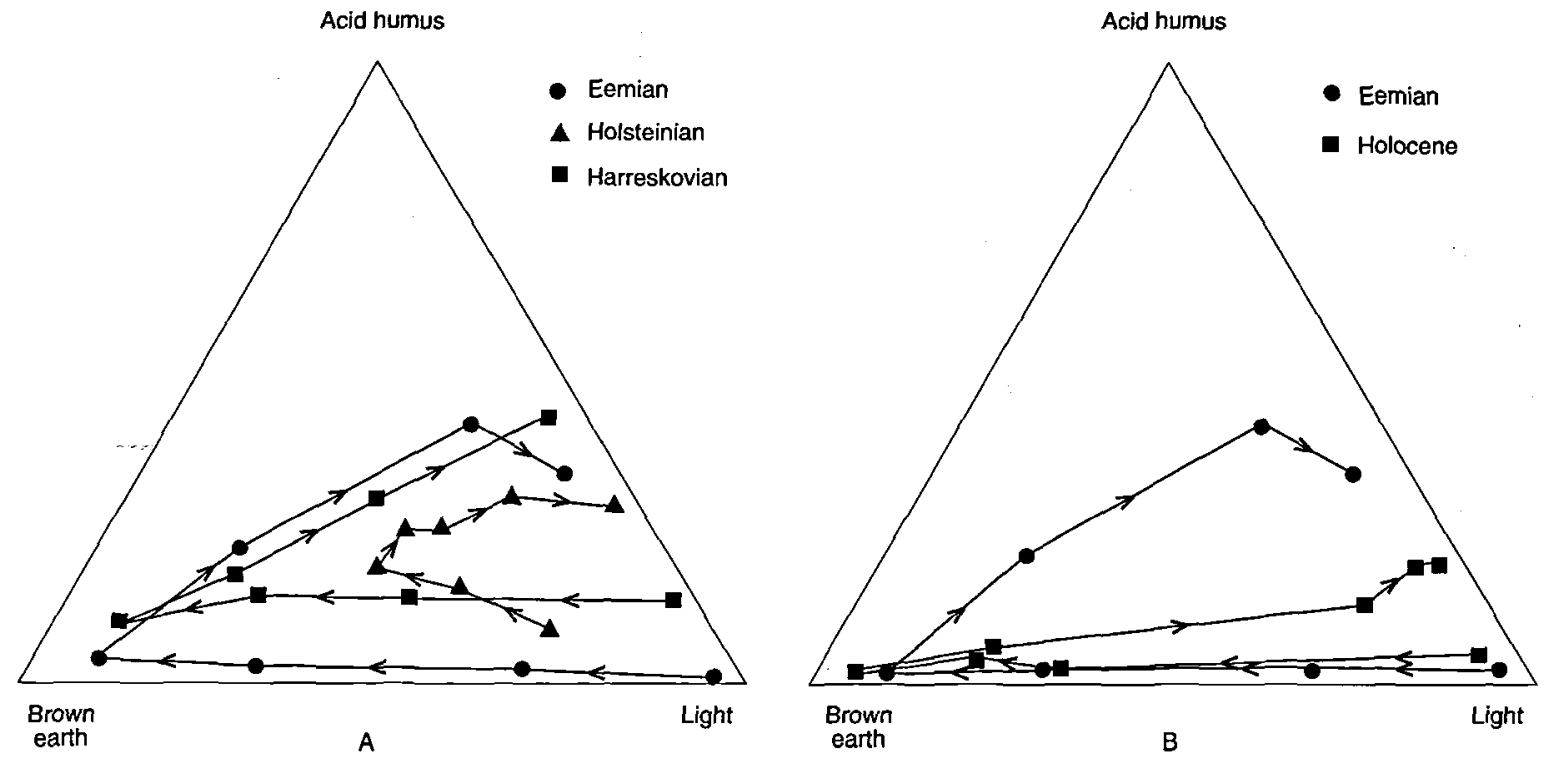

Fig. 5. A. Changes in vegetation and environment in three interglacials in Denmark. B. Vegetational change in the Holocene (Ove $\mathrm{S} \phi$, Thy) compared with the Eemian. The triangular diagrams indicate average pollen percentages in each pollen zone for vegetation of light-demanding plants without particular preferences to soil quality (Light, 100\% in the lower right-hand corner), for woodland on brown earth (Brown earth, $100 \%$ in the lower left-hand corner), and for vegetation on acid humus (Acid humus, $100 \%$ in the upper corner). The arrows indicate the direction of change from the oldest to the youngest pollen spectra within each interglacial (data from Andersen 1969 and Andersen \& Rasmussen in press).

ral activities. Hence, there is reason to introduce a new stage in the Holocene cycle, the Home sapiens stage (Birks 1986).

\section{Insolation and environment $0-10.000$ years}

The last minimum in insolation at about 20.000 years ago (Fig. 2, A) coincides with the maximum extent of the continental ice caps (Fig. 2, D). The insolation then increases with maximum values around 10.000 years ago and decreases again up to the present. These changes in insolation also affected the environment.

Climate simulations for the last 20.000 years based on general circulation models indicate an increase in annual average temperature in Scandinavia of about $20^{\circ} \mathrm{C}$ between 16.000 and 10.000 years and a temperature maximum at around 7.000 years (Birks 1990, based on data from Kutzbach \& Guetter 1986). ${ }^{18} 0$ measurements from Greenland ice cores and lake sediments in Switzerland and Poland indicate that this general temperature rise was modified by several cool oscillations and that the strongest temperature increase happened very suddenly, within around 50 years, at about 11.000 years (Dansgaard, White \& Johnsen 1989, Lotter, Eicher, Siegenthaler \& Birks 1992, Ralska-Jasiewiczowa, Geel, Goslar \& Kuc 1992). This event marks the transition to the Holocene.

Palaeoclimate reconstructions indicate decreasing tem- perature and increased precipitation in west Scandinavia since 10.000 years before today (Guiot, Harrison \& Prentice 1993). A reconstruction of the glacier equilibrium line altitude in Norway (Nesje, Kvamme Rye \& Løvlie 1991, Fig. 6, A) indicates a maximum at $6-8.000{ }^{14} \mathrm{C}$ years (corresponding to 7-9.000 sidereal years) and then a gradual decline with lesser oscillations up towards the present. This decline corresponds to a decrease in temperature about $2.5^{\circ} \mathrm{C}$. Changes in the altitude of the tree limit in Norway were parallel to the changes in the equilibrium line altitude (Fig. 6, B). The lowering of the tree line since the maximum at $8.000{ }^{14} \mathrm{C}$ years is around $300 \mathrm{~m}$ (Moe \& Odland 1992).

Another measure of the influence of the change in insolation is obtained by registrations of changes in the humification of peat layers in ombrotrophic raised bogs. The disintegration of the peat in raised bogs is highest at a high air temperature and low humidity and lowest at a low temperature and high humidity (Aaby 1976, 1978). The humification curves from Danish raised bogs (Fig. 6, $\mathrm{C}$ and $\mathrm{D}$ ) are strikingly similar to the curves for the equilibrium line and the tree line altitudes in Norway: high values at $7-8.000{ }^{14} \mathrm{C}$ years before now, and decreasing values up towards the present.

The humification curves from the raised bogs are very detailed and reflect a number of minor oscillations, which recur in the two examples shown in Fig. 6, C and D. Low humification at $4-3.000{ }^{14} \mathrm{C}$ years corresponds to a low equilibrium line altitude in Norway (Fig. 6, A). High 


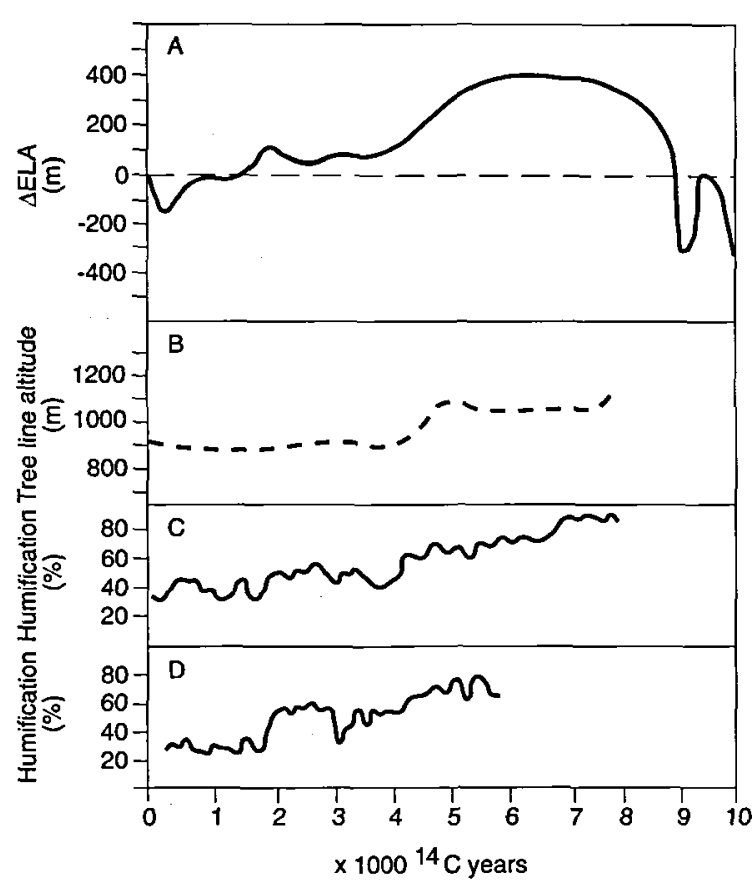

Fig. 6. Environmental change in Norway and Denmark in the Holocene. A. Deviations from the present of the altitude of the glacial equilibrium line (ELA) in Jotunheimen, in $\mathrm{m}$. B. Tree line altitude on Hardangervidda (after Moe and Odland 1992). C.-D. Degree of decomposition (humification) of peat layers in Danish ombrotrophic raised bogs. C, Abkær Mose, D, Fugls $\varnothing$ Mose. The time scale is in ${ }^{14} \mathrm{C}$ years before 1950 . Compiled after Nesje et al. (1991), Moe \& Odland (1992), Aaby in Andersen, Odgaard \& Aaby (1988). values occur at 3-2.000 years and conspicuous decreases around 2.000 and 500 years.

The decrease in insolation in the last 10.000 years is, therefore, reflected in the mountains of Norway and in raised bogs in Denmark. The shorter-term oscillations have not been explained convincingly, however, a regular periodicity seems to be present (260-year cycles, Aaby 1976). Another difficulty is due to the fact that the measured figures cannot be clearly resolved into parameters for temperature and precipitation. They rather express integrated effects of both.

\section{Changes in the biosphere $0-10.000$ years}

The increase in temperature 11.000 years ago was a starting point for the re-immigration of the temperate deciduous forest (Fig. 5B).These woodlands were fully established 6.000 years before now (Fig. 5, B). The natural succession was then interrupted by the intervention of Man, who from now on affected the environment with increasing force (the Homo sapiens stage). The newly introduced agriculture required space and open areas. The woodlands were therefore cleared to the benefit of pastures and fields. The agricultural exploitation in Denmark was particularly intensive in the west. The destruction of the forest began here in the Younger Stone Age and proceeded up to the last century, when the deforestation became nearly complete. Heath vegetation accompanied the land clearance on the sand plains of west Jutland (Fig. $7, \mathrm{~A})$. The expansion of heath resembles the development in the oligocratic stage of the interglacial cycles. The heath expansion on sandy soils in the Holocene was, however, arteficial and due to fire clearance by Man (Odgaard 1992). Grasslands, which include pastures as well as arable land, remained prominent on cleared areas

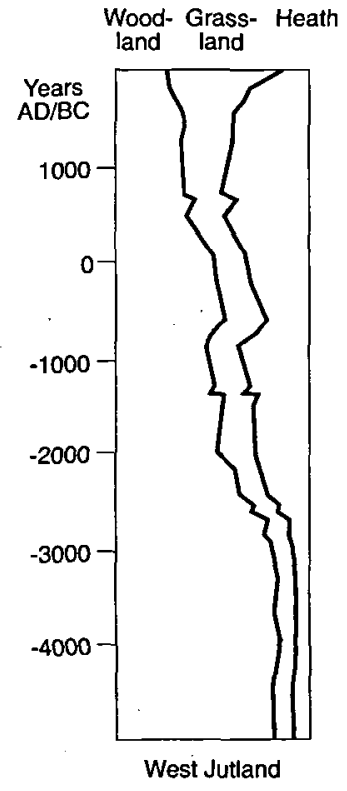

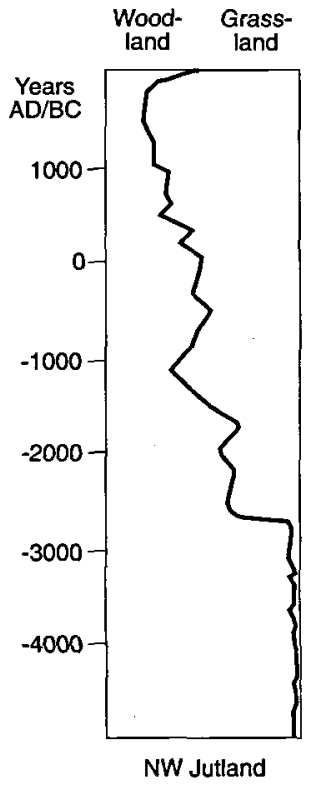

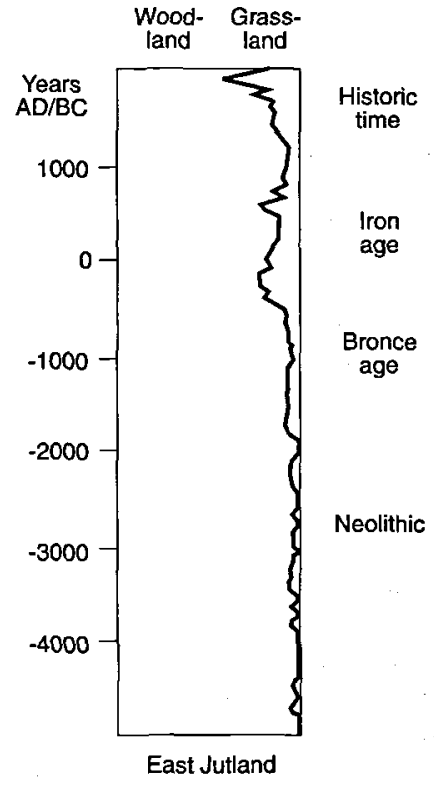

Fig. 7. Landscape development in Denmark during the past 7.000 years. West Jutland (Solsø, Odgaard 1992). Northwest Jutland (Hassing Huse Mose, Andersen 1992a). East Jutland (Fuglsø Mose, Aaby 1986). Time scale in calendar years. After Andersen (1991). 

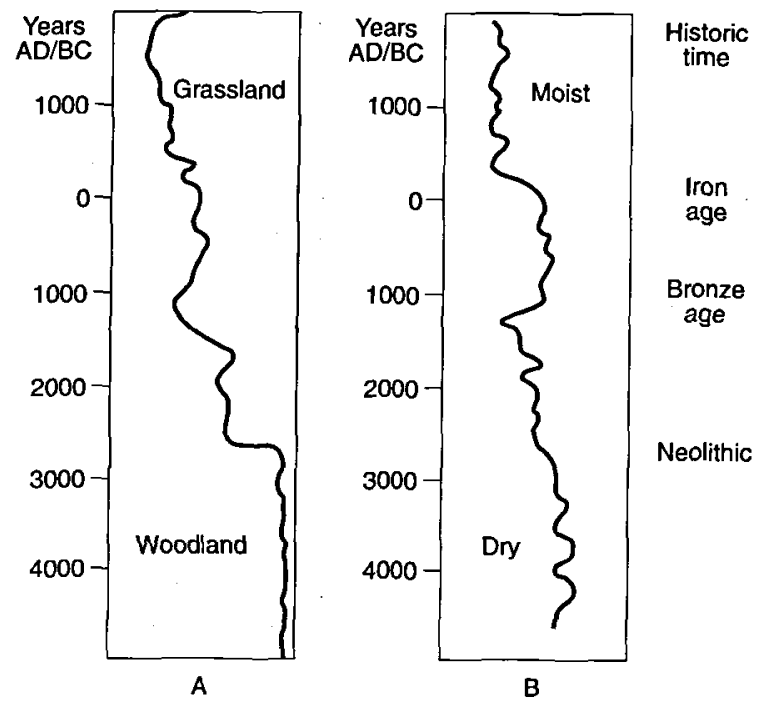

Fig. 8. A. Woodland clearance in Thy during the past 6.000 years. B. Humification of the peat in the raised bog Fugls $\varnothing$ Mose, Djursland. Time scale in calendar years. After Andersen (1992a).

of the fertile soils in northwest Jutland and heath vegetation was insignificant (Andersen 1992a, in press, Fig. 7, B).

In contrast to west Denmark, where artificial deforestation progressed continuously, human exploitation was less pronounced and discontinuous in major parts of eastern Denmark (Andersen 1991, Fig. 7, C,). Woodlands remained dominant here and prehistoric woodland clearance was restricted in space and time (Younger Bronze Age, Older Iron Age). More extensive forest clearance occurred in the Middle Ages and modern times, but deforestation was not as complete as in western Denmark. By the 19th century, west Denmark was void of woodlands, whereas woodland relics occurred commonly in the east Danish landscape, except for minor areas (e.g. northwest Sealand, the Roskilde Fjord-Køge Bugt area, Andersen 1991, 1992b, Aaby 1992).

The intensive land clearances in Thy, northwest Denmark, indicate increasing human exploitation. It appears that woodlands were cleared, whenever new land was needed. The curve for the agricultural exploitation in Thy is strikingly similar to the humification curves from the raised bogs (Fig. 8). The increase of the agricultural area apparently reflects the increase in moisture (or precipitation). The crops on grasslands and cereal fields in Denmark are considerably lower in years with a dry summer than in wet years, and fail entirely on the light soils (Aslyng 1986). The climate of the Younger Stone Age was considerably drier than today. With increasing moisture, increasing areas with lighter soils became available for agricultural expansion. The dry climate in the Younger Bronze Age and Older Iron Age coincides with retarded woodland clearance, and the increased moisture from around the Birth of Christ coincides with renewed exploitation, which continued up to the present day (Andersen 1992a, in press).

It appears that the resources available for agriculture in densely populated areas around the western Limfjord area depended on natural climatic changes. Large wooded areas were preserved in eastern Denmark, where agricultural activity and land exploitation were less intensive than in the western Limfjord area. The dependence on climatic change was therefore less pronounced there.

\section{Changes in environment $0-200$ years}

The detail of changes in environment reconstructed from studies of sediment columns increases the nearer we approach the present. The anthropogenous influences affect the environment during the past 200 years with increasing force.

The latest 260-year climatic cycles represented in raised bogs in Denmark are reflected in a temperature curve for central England reconstructed from meteorological observations (Aaby 1976, Fig. 9). Each 260-year cycle contains a more or less pronounced decrease in

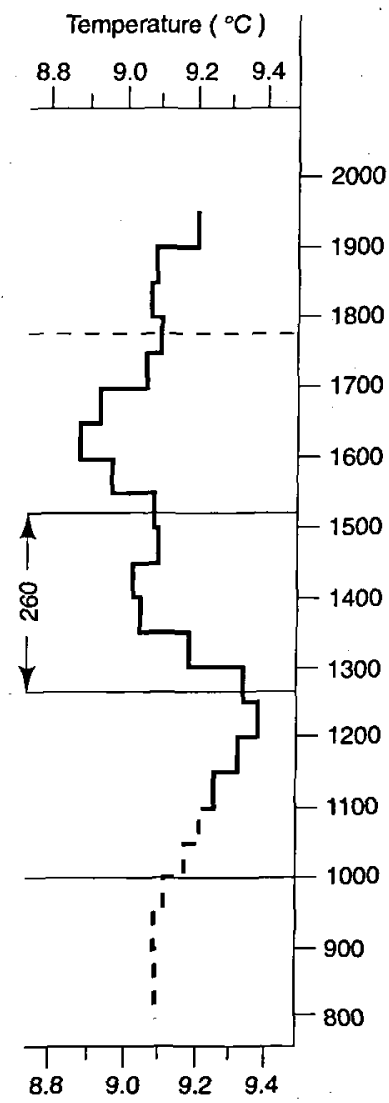

Fig. 9. Air temperature in central England. A.D. 800-1950 (50 year averages) compared with climate cycles from raised bogs in Denmark. After Aaby (1978). 


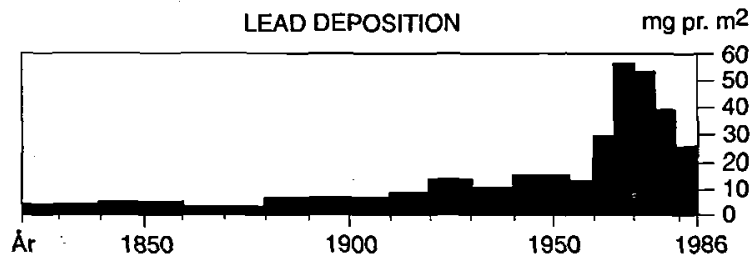

Fig. 10. Annual deposition of lead $\left(\mathrm{mg} / \mathrm{m}^{2}\right)$ on the raised bog Draved Mose, south Jutland 1820-1986. After Aaby (1987).

temperature followed by a temperature increase. The low temperatures in the 19th century and the increased temperatures in this century appear to be part of a natural development, which may bring a new temperature decrease in the next century, unless it is changed by anthropogenous pollution of the atmosphere (Aaby 1976).

Pollution of the atmosphere is reflected by increased deposition of industrially produced particles as measured in sediment columns. A classical example by now is the deposition of atmospherically transported lead particles on raised bogs (Aaby, Jacobsen \& Jacobsen 1979, Fig. $10)$. Low levels of naturally produced lead were doubled in the latter part of the 19th century, and the lead deposition increased gradually in the first half of this century. The deposition of lead increased by five times 1960-70 because of the introduction of lead as an anti-knocking agent in automobile petrol. This instalment of lead was reduced since 1975, but lead deposition was higher yet in 1980-86 than in the 1950'ties (Aaby 1987).

The curve for lead deposition reflects changes in environmental pollution by a single poisonous substance. Registration of soot spherules in lake sediments provide a measure for changes in air pollution caused by burning of fossil fuel (Odgaard 1993, Fig. 11). This kind of air pollution was insignificant at the turn of the century and increased conspicuously 1910-1940. The soot deposition accelerated strongly since World War II up to around 1970 and then decreased somewhat due to improved filtration of smoke, but not to pre-war levels.

Anthropogenous pollution of the atmosphere may result in changes in climate, or the atmosphere transports materials, which influence the biosphere and the hydrosphere. The hydrosphere may also become polluted by leaching of nutrients or outlets of waste water. Diatom communities in eutrophic lakes are particularly sensitive to changes in the content of phosphorus in the lake water. Statistical calibration of diatom analyses from lake sediments makes it possible to calculate the former concentration of phosphorus in the water and thereby to reconstruct background values for phosphorus concentration and the course of the pollution by phosphorus (Anderson, Rippey \& Gibson 1993, Anderson 1993). In the example shown (Fig. 12), the phosphorus concentration was moderate around 1850 . The concentration increased conspicuously in the late 19th century, probably as a result of increased arteficial drainage in the catchment area, and

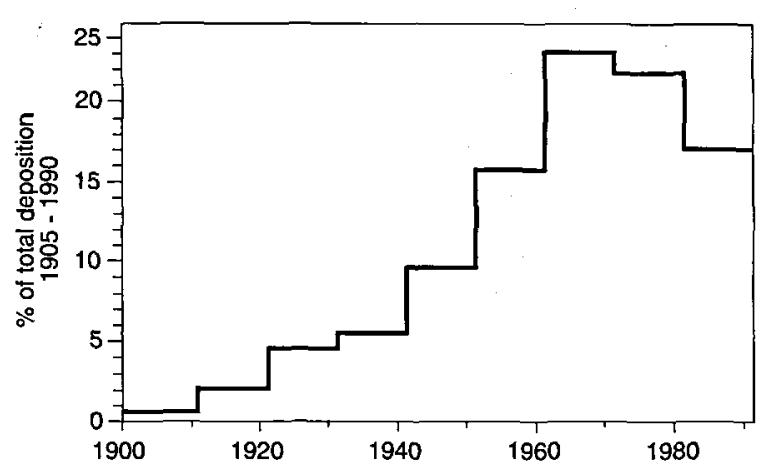

Fig. 11. Deposition of soot particles from combustion of fossi fuel in Danish lakes 1905-1990 in percentage of the total deposition 1905-1990. Average for 4 lakes. Redrawn after Odgaard (1993).

then to very high levels after 1950 as a result of increased use of fertilizers (Anderson \& Odgaard, in press).

Studies of environmental history based on sediments thus enable us to detect time horizons and strength of pollution of the environment, and to assess whether initiatives taken are sufficient for a return to more natural levels of pollution.

\section{Conclusion}

Examples of quantification of changes in the environment backward in time on various time scales and levels

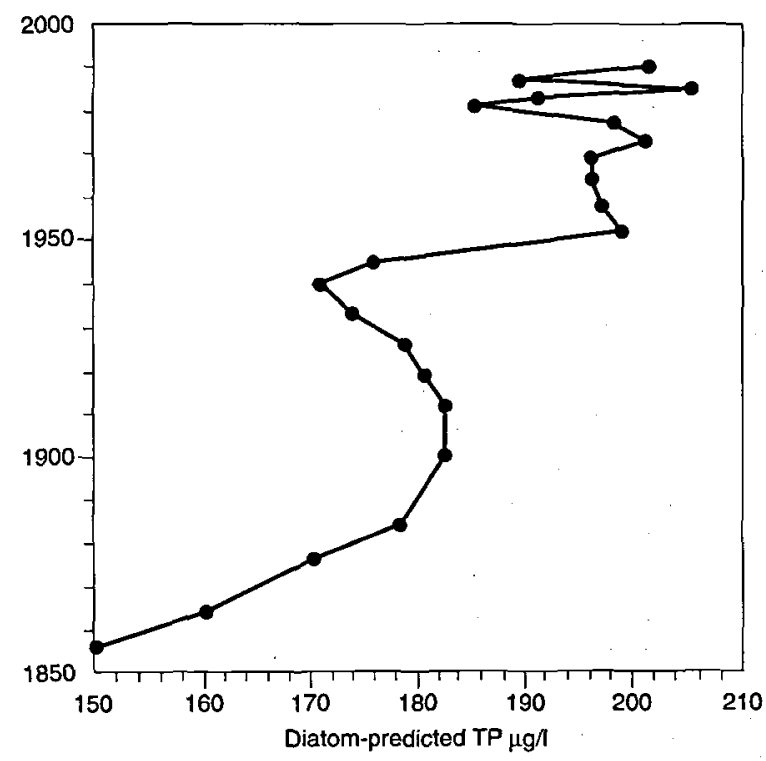

Fig. 12. Changes in concentrations of phosphorus in the water in Langes $\varnothing$, Funen, 1850-1990 based on statistical calibration of diatom analyses. Redrawn after Anderson \& Odgaard (in press). 
were discussed. Common to these are the geological methods used for the study of sediment columns varying from glacier ice, ocean and lake sediments to ombrotrophic peat. Changes in environment on the long time scales were predominantly extraterrestrially forced, but these forces were increasingly overshadowed by anthropogenic influences, the nearer we approach the present. The value of the measurements depends on the uniformity of the sediment columns and therefore the comparability of the results over a representative span of time.

\section{Dansk sammendrag}

Fndringer i miljøtilstanden bagud i tiden rekonstrueres ved målinger af geofysiske, geokemiske eller palæontologiske parametre i sedimentserier. Fndringer i miljøets elementære sfærer fremkaldes ved ændringer i solindstrålingen og ved gensidig påvirkning.

Den glaciale-interglaciale cyklus fremkaldes ved afvekslende maksima og minima i solindstrålingen og afspejler ændringer i biosfære og geosfære. Det sidste maksimum af solindstrålingen falder sammen med begyndelsen af Holocænet (omkring 11.000 år før nu) Den aftagende solindstråling påvirkede højden af glaciationsgrænsen og trægrænsen i Norge og luftfugtigheden $i$ Danmark. Løvskovens genetablering faldt sammen med temperaturmaksimet. Efter indførelsen af landbruget blev skovarealet reduceret i stigende grad, især i tæt beboede områder, hvor landbrugsudnyttelsen tiltog i takt med stigende nedbør.

Op mod nutiden påvirkes miljøet $\mathbf{i}$ stigende grad af mennesket. Det naturlige klimaforløb kan ændres af luftforurening. Luftforurening fra industrialiseringen kan registeres ved øget partikelnedfald på moser og i søer og forurening af vandmiljøet ved forøget tilførsel af næringsstoffer i ferskvandssøer.

\section{References}

Aaby, B. 1976: Cyclic climatic variations in climate over the past 5,500 yr reflected in raised bogs. Nature 263, 281-284.

Aaby, B. 1978: Cyclic changes in climate during 5,500 yrs. reflected in Danish raised bogs. Det Danske Meteorologiske Institut, Klimatologiske Meddelelser 4, 18-26.

Aaby, B. 1992: Sjællands kulturlandskaber i jernalderen. In Hansen, V. K. \& Nielsen, S. (eds) Sjællands Jernalder, 209226. Arkæologiske Skrifter 6. Arkæologisk Institut, Københavns Universitet.

Aaby, B., Jacobsen, J. \& Jacobsen, O. S. 1979: $\mathrm{Pb}-210$ dating and lead deposition in the ombrotrophic peat bog, Draved Mose, Denmark. Geological Survey of Denmark, Yearbook $1978,45-68$.

Andersen, S. T. 1965: Interglacialer og interstadialer i Danmarks Kvartær. Meddelelser fra Dansk Geologisk Forening 15, 496506.

Andersen, S. T. 1966: Interglacial succession and lake development in Denmark. The Palaeobotanist 15, 117-127.

Andersen, S. T. 1969: Interglacial vegetation and soil devel- opment. Meddelelser fra Dansk Geologisk Forening 19, 90102.

Andersen, S. T. 1991: Miljøhistorie/History of the environment. Årsberetning for 1990, Danmarks Geologiske Undersøgelse, Miljøministeriet, 40-45.

Andersen, S. T. 1992a: Miljøhistorie og kulturhistorie i det vestlige Limfjordsområde. Limfjordsprojektet, .Rapport 5, 87-91.

Andersen, S. T. 1992b: Pollen data for human impact on vegetation (based on methodological experiences). In Frenzel, B. (ed.) Evalutation of Land Surfaces cleared from Forests by Prehistoric Man in Early Neolithic Times and the Time of Migrating German Tribes, 1-11. Paläoklimaforschung 8. Gustav Fischer Verlag.

Andersen, S. T. in press: History of vegetation and agriculture at Hassing Huse Mose, Thy, northwest Denmark, since the Ice Age. Journal of Danish Archaeology.

Andersen, S. T., Odgaard, B. V. \& Aaby, B. 1988: Denmark. Report to the International Geological Correlation Programme, Project $158 \mathrm{~b}$. Manuscript, $17 \mathrm{pp}$.

Andersen, S. T. \& Rasmussen, P. in press: Geobotaniske undersøgelser af kulturlandskabets historie. Pollenanalyser fra gravhøje og søer i 1993. DGU Kunderapport.

Anderson, J. N. 1993: Natural versus anthropogenic change in lakes: The role of the sediment record. Trends in Ecology and Evolution 8, 356-361.

Anderson, N. J., Rippey, B. \& Gibson, C. E. 1993: A comparison of sedimentary and diatom-inferred phosphorus profiles: implications for defining pre-disturbance nutrient conditions. Hydrobiologia 253, 357-366.

Anderson, N. J. \& Odgaard, B. V. in press: Recent palaeolimnology of three shallow Danish lakes. Hydrobiologia.

Aslyng, H. C. 1986: Klima, vandforsyning og planteproduktion. In Jensen, K. M. \& Reenberg, A. (eds.) Landbrugsatlas Danmark, 10-16. Atlas over Danmark, 2, 4.

Birks, H. J. B. 1986. Late-Quaternary biotic changes in terrestrial and lacustrine environments, with particular reference to north-west Europe. In Berglund, B. E. (ed.) Handbook of Holocene Palaeoecology and Palaeohydrology, 3-65. John Wiley and Sons.

Birks, H. J. B. 1990: Changes in vegetation and climate during the Holocene of Europe. In Boer, M. M. \& Groot, R. S. de (eds.) Landscape- Ecological Impact of Climatic Change, 133-157. IOS Press.

Dansgaard, W., White, J. W. C. \& Johnsen, S. J. 1989: The abrupt termination of the Younger Dryas climate event. Nature 339, 532-534.

Emiliani, C. 1993: Milankovitch theory verified. Nature 364, $583-584$.

Genthon, C., Barnola, J. M., Raynaud, D., Lorius, C., Jouzel, J., Barkov, N. I., Korotkevich, Y. S. \& Kotlyakov, V. M. 1987: Vostok ice core: climatic response to $\mathrm{CO}_{2}$ and orbital forcing changes over the last climatic cycle. Nature 329, 414-418.

Greenland Ice-Core Project (GRIP) Members 1993: Climate instability during the last interglacial period recorded in the GRIP ice core. Nature 364, 203-207.

Guiot, J., Harrison, S. P. \& Prentice, I. C. 1993: Reconstruction of Holocene precipitation patterns in Europe using pollen and lake-level data. Quaternary Research 40, 139-149.

Guiot, J., Pons, A., Beaulieu, J. L. de \& Reille, M. 1989: A 140,000 year continental climate reconstruction from two European pollen records. Nature 338, 309-313.

Hammen, T. van der 1979: Changes in life conditions on Earth during the past one million years. Det Kongelige Danske Videnskabernes Selskab, Biologiske Skrifter 22, 32 pp. Munksgaard.

Hansen, J. M. 1984: Geologi for enhver. Danmarks Undergrund og Răstofferne. Danmarks Geologiske Undersøgelse, Miljøministeriet. 88 pp. C. A. Reitzels Forlag.

Hays, J. D., Imbrie, J. \& Shackleton, N. J. 1976: Variations in the Earth's orbit: Pacemaker of the ice ages. Science 194, 1121-1132. 
Iversen, J. 1957: The bearing of glacial and interglacial epochs on the formation and extinction of plant taxa. Uppsala Universitets Årsskrift 1958, 6, 210-215.

Jouzel, J., Lorius, C., Petit, J. R., Genthon, C., Barkoy, N. I., Kotlyokov, V. M. \& Petrov, V. M. 1987: Vostok ice core: a continuous isotopetemperature record over the last climatic cycle $(160,000$ years $)$. Nature $329,403-407$.

Kutzbach, J. E. \& Guetter, P. J. 1986. The influence of changing orbital parameters and surface boundary conditions on climate simulations for the past 18000 years. Journal of Atmospheric Sciences 43, 1726-1759.

Lotter, A. F., Eicher, U., Siegenthaler, V. \& Birks, H. J. B. 1992: Lateglacial climatic oscillations as recorded in Swiss lake sediments. Journal of Quaternary Science 7, 187-204.

Mangerud, J. 1989: Correlation of the Eemian and the Weichselian with deep sea oxygen isotope stratigraphy. Quaternary International $3 / 4,1-4$

Martinson, D. G., Pisias, N. G., Hays, J. D., Imbrie, J., Moore, T. C. \& Shackleton, N. J. 1987: Age, dating and orbital theory of the ice ages: Development of a high resolution 0 to 300,000 year chronostratigraphy. Quaternary Research 27, 1-29.
Moe, D. \& Odland, A. 1992: The influence of the temperature climate on the vertical distribution of Alnus incana (Betulaceae) through the Holocene in Norway. Acta Botanica Fennica 144, 35-49.

Nesje, A., Kvamme, M., Rye, N. \& Løvlie, R. 1991: Holocene glacial and climate history of the Jostedalsbreen region, western Norway: evidence from lake sediments and terrestrial deposits. Quaternary Science Reviews 10, 87-114.

Odgaard, B. V. 1992: The fire history of Danish heathland areas as reflected by pollen and charred particles in lake sediments. The Holocene 2, 218-226.

Odgaard, B. V. 1993: The sedimentary record of spheroidal carbonaceous fly-ash particles in shallow Danish lakes. Journal of Paleolimnology 8, 171-187.

Pons, A., Beaulieu, J.-L. de, Guiot, J. \& Reille, M. 1991: Le pollen remonte le temps climatique. La Recherche 22, 518 520.

Ralska-Jasiewiczowa, M., van Geel, B., Goslar, T., and Kuc, T. 1992: The record of the Late Glacial/Holocene transition in the varved sediments of lake Gosciaz, central Poland. Sveriges Geologiska Undersökning Ca 81, 257-268. 